\title{
PENGARUH KOMUNIKASI INTERNAL DALAM MEMBANGUN BUDAYA ORGANISASI
}

\section{The Influence of Internal Communication in Building Organizational Culture}

\author{
Nur Annisa Agustini ${ }^{1}$, Ninuk Purnaningsih ${ }^{2}$ \\ ${ }^{1}$ Mahasiswa Departemen Sains Komunikasi dan Pengembangan Masyarakat, \\ Fakultas Ekologi Manusia, Institut Pertanian Bogor \\ ${ }^{2}$ Dosen Departemen Sains Komunikasi dan Pengembangan Masyarakat, \\ Fakultas Ekologi Manusia, Institut Pertanian Bogor \\ E-mail: nurannisagstn@ rocketmail.com
}

\begin{abstract}
Internal communication can be understood as the foundation and building of an organizational culture. The existence of an organizational culture that has been firmly held by its employees will greatly support the process of the main purpose of the company. This research aims to analyze internal communication in building organization oriented on the results and time, using a sample of 30 respondents. This research is conducted by using quantitative approach supported by qualitative data. The results of this study indicate a change given by internal communication in building an organizational culture, which is one aspect is the leadership power that becomes a good example for the employees. A strong leadership role to provide direction and start with a good communication process, will get a positive response from its employees in work and improve the maximum work.
\end{abstract}

Keywords : agribusiness company, internal communication, organizational culture

\begin{abstract}
ABSTRAK
Komunikasi internal dapat dipahami sebagai pondasi dan bangunan dari sebuah budaya organisasi. Adanya budaya organisasi yang telah di pegang teguh oleh para karyawannya akan sangat mendukung proses pencapaian tujuan utama dari perusahaan. Penelitian ini bertujuaan untuk menganalisis pengaruh komunikasi internal dalam membangun budaya organisasi yang khususnya budaya organisasi berorientasi pada hasil dan tim, dengan menggunakan sampel sebanyak 30 responden. Penelitian ini dilaksanakan dengan menggunakan pendekatan kuantitatif yang didukung oleh data kualitatif. Hasil penelitian ini menunjukkan adanya pengaruh yang diberikan oleh komunikasi internal dalam membangun budaya organisasi, yaitu salah satu aspeknya adalah kekuatan leadership yang menjadi contoh baik bagi para karyawannya. Peran pimpinan yang kuat untuk memberikan arahan dan memulai dengan proses komunikasi yang baik, akan mendapatkan respon positif dari para karyawannya dalam bekerja dan menghasilkan hasil kerja yang maksimal.
\end{abstract}

Kata Kunci : budaya organisasi, komunikasi internal, perusahaan agribisnis

\section{PENDAHULUAN}

Organisasi tidak terbentuk karena adanya surat atau dokumen persetujuan, tetapi organisasi ada sejak adanya interaksi atau komunikasi tertentu diantara orang-orang yang menunjukkan bahwa mereka tengah berorganisasi (Morissan, 2009). Aspek penting dalam suatu organisasi adalah sumber daya manusia, yaitu 
orang-orang yang aktif berperan dalam melakukan perencanaan, pelaksanaan dan pengendalian dalam mewujudkan tujuan organisasi. Manusia sebagai salah satu sumber daya organisasi yang sangat penting dalam mewujudkan tujuan organisasi melalui bakat, karya, kreativitas dan peran nyatanya untuk mencapai tujuan yang diinginkan (Harsono dkk 2015). Oleh karena itu, sumber daya manusia dianggap sebagai kunci keberhasilan dalam organisasi, dikarenakan hampir setiap kegiatan yang dilaksanakan menggunakan sumber daya manusia sebagai tenaga kerja dan komponen penting dalam organisasi. Menurut UU No. 13 tahun 2003 tentang Ketenagakerjaan, tenaga kerja adalah setiap orang yang mampu melakukan pekerjaan guna menghasilkan barang dan atau jasa, baik untuk memenuhi kebutuhan sendiri maupun untuk masyarakat.

Saat ini kebutuhan masyarakat semakin meningkat setiap tahunnya terhadap suatu barang, baik barang untuk dipakai maupun dikonsumsi sehari-hari. Meskipun peningkatan kebutuhan setiap tahunnya tidak terlalu signifikan, namun hal ini mengindikasikan bahwa masyarakat memiliki kebutuhan berupa barang yang harus dipenuhi setiap tahunnya. Sayuran contohnya yang merupakan komoditas berupa bahan pangan yang dihasilkan oleh pertanian. Sayuran memiliki peranan penting bagi masyarakat dalam pemenuhan kebutuhan gizi terutama sebagai sumber vitamin, mineral, serat dan antioksidan. Sebagai komoditas bahan pangan pertanian yang memiliki prospek bisnis yang cukup cerah, saat ini sudah banyak beberapa bisnis berbasis pertanian yang sukses dalam memproduksi dan mendistribusikan hasil olahannya untuk masyarakat. PT Sayuran Siap Saji Sukamanah, Bogor Jawa Barat merupakan salah satu perusahaan agribisnis yang memproduksi sayuran segar siap saji dalam bentuk sudah dipotong (fresh cut) dan juga dalam bentuk utuh (whole). Sayuran segar yang dihasilkan oleh PT Sayuran Siap Saji ini mendapatkan penanganan dengan standarisasi Hazard Analysis Critical Control Point (HACCP), hal ini dilakukan untuk mendapatkan sayuran segar dan berkualitas.

Sebelum tahun 1990an, fokus perusahaan lebih mengedepankan bagaimana berkomunikasi dengan pihak eksternal, hal ini di paparkan oleh Smith (1991) yang menjelaskan komunikasi ke pihak eksternal ditujukan untuk meningkatkan volume penjualan, membangun corporate image dan target utama yaitu para pemegang saham, komunitas keuangan, pelanggan dan masyarakat umum. Seiring perkembangan zaman, hampir sebagian besar perusahaan saat ini sudah mulai memperhatikan bagaimana hubungan internal yang terjalin dalam perusahaannya. Seperti contohnya perusahaan agribisnis PT Sayuran Siap Saji, pencapaian yang telah didapat oleh PT Sayuran Siap Saji tidak terlepas dari peran pihak-pihak internal yang terlibat didalamnya untuk melakukan perencanaan, pengawasan, pengembangan dan lain-lain.

Argenti (2013) menyatakan bahwa suatu organisasi membutuhkan komunikasi internal antara atasan dengan bawahan untuk menjaga hubungan agar saling terbuka dalam hal pekerjaan. Maka dari itu, tujuan komunikasi internal yang terjalin di PT Sayuran Siap Saji adalah untuk menjaga kekompakan dan hubungan antara sesama pegawai maupun dengan atasan agar tercapai tujuan dari PT Sayuran Siap Saji. Komunikasi internal yang terjalin dengan baik akan sejalan dengan budaya organisasi yang ada di dalam suatu organisasi. Menurut Sutrisno (2010), budaya organisasi diartikan sebagai seperangkat nilai-nilai, keyakinankeyakinan, atau norma-norma yang harus dipahami, dijiwai dan dipraktekkan 
dalam organisasi yang dianut bersama oleh para anggota organisasi sebagai pedoman perilaku dan memecahkan masalah-masalah organisasi.

Namun budaya organisasi khususnya dalam bidang pertanian, yaitu perusahaan agribisnis yang berlokasi di sekitar pedesaan cenderung memiliki budaya organisasi yang relatif rendah dibandingkan dengan budaya organisasi di bidang lainnya. Hal ini berkaitan dengan sumber daya manusianya dalam memahami budaya organisasi yang ada dalam perusahaan. Melalui narasumber dari pihak PT Sayuran Siap Saji, pihaknya menjelaskan bahwa ketidakdisiplinan dari para karyawan menghambat proses produksi yang dijalankan oleh perusahaan, dan pihak manajemen memberlakukan sanksi sebagai peraturan yang telah diterapkan dalam PT Sayuran Siap Saji.

Tsai (2001) menyarankan bahwa di dalam suatu organisasi, proses pembelajaran (learning) dapat meningkatkan transfer pengetahuan antar unit kerja yang berbeda dan juga mengindikasikan bahwa terdapat komunikasi internal yang efektif dengan memasukkan unsur pembelajaran sebagai key function. Strategi komunikasi yang diterapkan oleh PT Sayuran Siap Saji dengan cara berusaha berbaur dengan karyawannya, menghasilkan respon dan perubahan yang cukup signifikan, yaitu para karyawan dengan mudah memahami aturan dan perintah yang dimaksudkan oleh manajemen atau pun kepala produksi. Pada prosesnya, karyawan maupun pihak manajemen di PT Sayuran Siap Saji secara keseluruhan perlu berkomunikasi antar sesama ataupun dengan atasan dan bawahan agar tidak terjadi kesalahpahaman dalam melaksanakan tugasnya. Argenti (2013) menyatakan bahwa komunikasi internal yang baik dibutuhkan partisipasi dari bawahan kepada atasan untuk menyampaikan ide, kendala, dan pendapat.Segala proses komunikasi internal tersebut akan membentuk budaya organisasi yang menjadi sebuah hubungan fungsional, yaitu budaya organisasi terbentuk karena adanya komunikasi yang terjalin di dalam organisasi tersebut. Oleh karena itu, dibutuhkan penelitian lebih lanjut bagaimana pengaruh komunikasi internal dalam membangun budaya organisasi di PT Sayuran Siap Saji.

Pertanyaan dari penelitian ini adalah 1) Bagaimana proses komunikasi internal yang terjalin di PT Sayuran Siap Saji?, 2) Bagaimana karakteristik budaya organisasi yang ada di PT Sayuran Siap Saji?, dan 3) Faktor-faktor apa saja yang dapat mempengaruhi komunikasi internal dalam membangun budaya organisasi di PT Sayuran Siap Saji?

\section{TINJAUAN PUSTAKA}

\section{Komunikasi}

Komunikasi adalah proses penyampaian pesan oleh seseorang kepada orang lain untuk memberi tahu atau untuk mengubah sikap, pendapat, atau perilaku, baik langsung secara lisan maupun tak langsung melalui media (Effendy, 2008). Proses komunikasi itu sendiri erat kaitannya dalam kehidupan sehari-hari atau dalam kehidupan bermasyarakat, tanpa komunikasi seseorang tidak dapat memahami orang lain, atau seseorang tersebut tidak dapat bertukar informasi maupun mendapatkan informasi dari orang lain. Terjadinya komunikasi merupakan konsekuensi hubungan sosial, dimana masyarakat paling sedikit terdiri dari dua orang yang saling berhubungan satu sama lain sehingga hubungan tersebut menimbulkan interaksi sosial yang disebabkan oleh proses komunikasi itu sendiri. Pengertian komunikasi harus ditinjau dari dua sudut pandang yaitu pengertian 
komunikasi secara umum dan pengertian komunikasi secara paradigmatik, agar menjadi jelas bagaimana pelaksanaan komunikasi.

\section{Komunikasi Organisasi}

Menurut Sutrisno (2010), komunikasi organisasi adalah perilaku pengorganisasian yang terjadi dan bagaimana mereka terlibat dalam proses itu, bertransaksi dan memberi makna atas apa yang sedang terjadi. Sifat terpenting komunikasi organisasi adalah penciptaan pesan, penafsiran, dan penanganan kegiatan anggota organisasi, bagaimana proses komunikasi organisasi terjalin bergantung kepada seseorang atau anggotanya memaknai atau menafsirkan mengenai hal yang ada di dalam organisasinya. Komunikasi secara efektif dalam organisasi sangat diperlukan dalam kelancaran untuk mencapai tujuan, namun untuk mencapainya perlu juga diperhatikan faktor-faktor penghambatnya. Hal tersebut dikarenakan tidak semua anggota dapat memahami atau menafsirkan pesan secara sama seperti yang dimaksudkan, melainkan ada persepsi yang berbeda diantara semua anggota. Komunikasi organisasi ini merupakan ruang bagi setiap karyawan yang bekerja di dalam organisasi tersebut untuk melakukan proses komunikasi internal dengan sesama karyawan, atasan maupun dengan bawahannya.

\section{Komunikasi Internal}

Komunikasi internal menurut Brennan dalam Suprapto (2011) adalah pertukaran gagasan di antara para administrator dan karyawan dalam suatu perusahaan atau jawatan yang menyebabkan terwujudnya perusahaan atau jawatan tersebut lengkap dengan strukturnya yang khas (organisasi), dan pertukaran gagasan secara horizontal dan vertikal di dalam perusahaan atau jawatan yang menyebabkan pekerjaan berlangsung (operasi dan manajemen). Komunikasi internal pada dasarnya harus memiliki informasi yang sesuai dengan kebutuhan (tidak kelebihan/kebanyakan) dan juga kelengkapan informasi yang dibutuhkan bagi karyawan berkaitan dengan tugas-tugas, sehingga menghasilkan arti pentingnya suatu komunikasi timbal balik antara atasan dengan karyawan (Putranto 2012). Andjani dan Prianti (2010) mengatakan bahwa komunikasi internal dianggap sebagai salah satu solusi dalam memecahkan permasalahan internal yang ada dalam suatu perusahaan, dimana komunikasi internal memulai dengan memperbaiki hubungan karyawan dengan atasan atau pun sebaliknya, dan hubungan dengan sesama karyawan. Argenti (2013) menyatakan bahwa suatu organisasi membutuhkan komunikasi internal antara atasan dengan bawahan untuk menjaga hubungan agar saling terbuka dalam hal pekerjaan. Komunikasi internal yang baik dibutuhkan partisipasi dari bawahan kepada atasan untuk menyampaikan ide, kendala, dan pendapat. Oleh karena itu, pada saat ini sebagian besar karyawan menuntut adanya partisipasi dalam dialog di tempat kerja yang mendorong perubahan organisasi. Partisipasi dianggap penting untuk menjaga keterlibatan karyawan di semua tingkat organisasi tanpa mengedepankan tanggung jawab pekerjaan. Selain itu, partisipasi dapat mendorong kekompakan antara sesama karyawan maupun dengan atasan. Sehubungan dengan perkembangan ini, komunikasi harus berupa proses dua arah yang menghasilkan umpan balik, agar pendapat karyawan dapat didengar dan dilakukan oleh atasannya. 


\section{Menerapkan Komonikasi Internal yang Efektif}

Menurut Argenti (2013), cara terbaik untuk menilai keefektifan usaha komunikasi internal perusahaan adalah dengan menentukan sikap karyawan tentang perusahaan. Tsai (2001) menyarankan bahwa di dalam suatu organisasi, proses pembelajaran (learning) dapat meningkatkan transfer pengetahuan antar unit kerja yang berbeda dan juga mengindikasikan bahwa terdapat komunikasi internal yang efektif dengan memasukkan unsur pembelajaran sebagai key function. Efektifitas dari komunikasi internal ini akan tergantung dari kapasitas pembelajaran yang ada dalam organisasi. Orsini (2000) menjelaskan bahwa komunikasi internal yang efektif adalah hal yang mendasar bagi perusahaan untuk menjalankan tata kelola organisasi atau bisnis yang baik dan kontrol yang penting untuk memahami arah dari organisasi. Untuk meningkatkan efektivitas komunikasi internal diperlukan pendekatan partisipatif dari berbagai pihak. Pada akhirnya, dorongan komunikasi internal yang efektif memperkuat keyakinan karyawan bahwa mereka adalah aset penting bagi perusahaan.

Komunikasi internal sebagai proses penting yang melibatkan pertukaran pengetahuan dan informasi dan juga organisasi dan individu perlu menguasai komunikasi internal agar efektif. Maka dari itu penelitian ini mengadaptasi teori Markgraf (2003), mengenai efektivitas komunikasi internal dinilai dengan modifikasi beberapa variabel sebagai berikut:

(1) Komunikasi dua arah adalah komunikasi dijalankan dua arah dari Manajemen ke karyawan dan sebaliknya

(2) Kemampuan inter-personal adalah kemampuan setiap karyawan dalam menyampaikan pesan/informasi kepada pihak lain di internal organisasi

(3) Kesadaran dan budaya risiko adalah setiap terdapat potensi risiko karyawan secara otomotis dapat mengidentifikasi dan melaporkan sesuai hirarki yang ditetapkan

(4) Kejelasan pesan/informasi adalah pengirim dan penerima pesan/informasi memiliki persepsi yang sama

(5) Frekuensi pesan/informasi adalah aspek yang melihat intensitas seseorang dalam memperoleh pesan atau informasi

(6) Pembelajaran berkala adalah sosialisasi/refreshment dilakukan secara berkala

(7) Tatakelola pengelolaan risiko adalah pemantauan melalui jenjang komite telah berjalan secara berkala

(8) Struktur komunikasi internal adalah lapis pertahanan pengelolaan risiko operasional/kelangsungan usaha telah berjalan efektif

(9) Pengetahuan manajemen adalah pemahaman manajemen atas alur komunikasi untuk pengelolaan risiko operasional dan kelangsungan usaha

(10) Kekuatan leadership adalah peran pimpinan dalam pengelolaan risiko operasional dan kelangsungan usaha

Efektivitas komunikasi internal yang dijabarkan oleh Markgraf (2003) adalah menyangkut pengelolaan risiko dan keberlangsungan usaha dalam suatu perusahaan, yaitu bagaimana caranya dengan komunikasi internal yang efektif akan meminimalkan risiko yang terjadi, serta merespon seberapa cepat atau sigap perusahaan bertindak untuk recovery atau mengembalikan kepada keaadaan semula ketika terjadi kendala dalam aktivitas perusahaan. 


\section{Budaya}

Budaya atau kebudayaan berasal dari bahasan Sansekerta, yaitu "buddhayah", bentuk jamak dari "buddhi" (budi atau akal) diartikan sebagai hal yang berkaitan dengan budi dan akal manusia (Ridwan, 2016). Budaya mencakupi semua cara yang telah terorganisasi, kepercayaan, norma, nilai-nilai budaya implisit, serta asumsi-asumsi dasar yang mengandung suatu perintah. Menurut Doloksaribu (2010), budaya sebagai dasar menjadi hal yang penting ketika membicarakan budaya organisasi, karenanya budaya atau kebudayaan dimaknai sebagai sesuatu yang akan mempengaruhi tingkat pengetahuan dan meliputi sistem ide atau gagasan yang terdapat dalam pikiran manusia yang disosialisasikan secara turun-temurun dan bersifat abstrak.

\section{Budaya Organisasi}

Budaya organisasi yaitu sebagai suatu sistem makna bersama yang dianut oleh anggota-anggota yang membedakan organisasi itu dengan organisasi yang lain (Robbins, 2002). Selain itu budaya organisasi sering diartikan sebagai seperangkat nilai-nilai, keyakinan-keyakinan, atau norma-norma yang harus dipahami, dijiwai dan dipraktekkan dalam organisasi yang dianut bersama oleh para anggota organisasi sebagai pedoman perilaku dan memecahkan masalahmasalah organisasi (Sutrisno, 2010). Hasil penelitian Melina dan Ratnawati (2012) menyebutkan bahwa budaya organisasi memiliki pengaruh yang cukup besar dalam menentukan kinerja karyawan, maka dari itu perusahaan melakukan upaya untuk memperkuat dan mempertahankan budaya yang ada dengan cara pihak perusahaan mengadakan sosialisasi mendalam mengenai visi, misi, nilainilai serta peraturan-peraturan yang ada pada perusahaan agar karyawan lebih memahami tugas dan tanggung jawab yang mereka miliki, sehingga hasilnya sesuai dengan arah dan tujuan perusahaan.

Morissan (2009) menyatakan esensi kehidupan organisasi dapat ditemukan pada budaya yang dimiliki organisasi bersangkutan. Budaya bukanlah sesuatu yang dimiliki organisasi, tetapi organisasi itu sendiri adalah budaya. Budaya organisasi memiliki karakteristik yang dikemukakan oleh Robbins (2002) yang memberikan tujuh karakteristik budaya organisasi sebagai berikut:

(1) Inovasi dan keberanian mengambil risiko (Inovation and risk taking), adalah sejauh mana organisasi mendorong para karyawan bersikap inovatif dan berani mengambil resiko. Selain itu bagaimana organisasi menghargai tindakan pengambilan risiko oleh karyawan dan membangkitkan ide karyawan;

(2) Perhatian terhadap detil (Attention to detail), adalah sejauh mana organisasi mengharapkan karyawan memperlihatkan kecermatan, analisis dan perhatian kepada rincian.

(3) Berorientasi kepada hasil (Outcome orientation), adalah sejauh mana manajemen memusatkan perhatian pada hasil dibandingkan perhatian pada teknik dan proses yang digunakan untuk meraih hasil tersebut.

(4) Berorientasi kepada manusia (People orientation), adalah sejauh mana keputusan manajemen memperhitungkan efek hasil-hasil pada orang-orang di dalam organisasi.

(5) Berorientasi tim (Team orientation), adalah sejauh mana kegiatan kerja diorganisasikan sekitar tim-tim tidak hanya pada individu-individu untuk mendukung kerjasama. 
(6) Agresifitas (Aggressiveness), adalah sejauh mana orang-orang dalam organisasi itu agresif dan kompetitif untuk menjalankan budaya organisasi sebaik-baiknya.

(7) Stabilitas (Stability), adalah sejauh mana kegiatan organisasi menekankan status quo sebagai kontras dari pertumbuhan.

Hasil penelitian Kadafi (2010) menyimpulkan bahwa kerjasama tim dan orientasi hasil mempunyai peranan yang sangat penting terhadap kinerja pada suatu organisasi, implikasi penting bagi organisasi diantaranya: (1) perhatian untuk mempertahankan budaya kerja, yaitu budaya kerja haruslah dijadikan nilainilai yang menjadi pedoman karyawan untuk membantu perusahaan meningkatkan kinerja karyawan dan tujuan perusahaan, (2) perhatian manajemen terhadap proses seleksi karyawan, dimana manajemen harus lebih fokus memperkerjakan calon karyawan yang mempunyai nilai-nilai yang sejalan dengan nilai-nilai pada organisasi, dan (3) perhatian terhadap sosialiasi nilai-nilai organisasi perlu dilakukan oleh manajemen untuk menginformasikan apa yang harus dan tidak harus dilakukan oleh karyawan akan berpengaruh terhadap pemahaman nilai-nilai organisasi.

Robbins (2002) memaparkan tujuh karakteristik mengenai budaya organisasi, dari ketujuh karakteristik tersebut yang dapat mewakili suatu organisasi yaitu karakteristik budaya organisasi yang berorientasi pada hasil dan budaya organisasi yang berorientasi pada tim. Maka dapat ditarik menjadi satu kesatuan, yaitu sebagai budaya organisasi yang berorientasi pada hasil dan tim. Pengertian tersebut sama halnya dengan penelitian Kadafi (2010) yang hasilnya melihat budaya organisasi yang berorientasi pada hasil dan tim dari budaya kerja yang ada, perhatian terhadap seleksi calon karyawan yang berkompeten, serta sosialisasi dari pihak organisasi mengenai nilai-nilai yang terdapat dalam organisasi.

\section{Kerangka Pemikiran}

Komunikasi internal dapat dijadikan sebagai alat dan sarana komunikasi untuk menyampaikan informasi, memelihara hubungan antara semua anggota yang berada dalam organisasi, menghindari terjadinya kesalahpahaman yang mungkin terjadi dalam organisasi, dan juga sebagai sarana dan media dalam penyampaian aspirasi maupun keinginan para pihak internal atau anggota organisasi terhadap organisasi secara keseluruhan. Menurut Markgraf (2003) mengemukakan modifikasi variabel komunikasi internal yang dianggap relevan untuk menganalisis komunikasi internal yang terjalin di PT Sayuran Siap Saji yang terdiri dari komunikasi dua arah, kemampuan inter-personal, kesadaran dan budaya risiko, kejelasan pesan/informasi, frekuensi pesan/informasi, pembelajaran berkala, tatakelola pengelolaan risiko, struktur komunikasi internal, pengetahuan manajemen dankekuatan leadership. Variabel terpengaruh dalam penelitian ini menggunakan konsep budaya organisasi yang dijabarkan oleh Robbins (2002) dengan ketujuh karakteristik budaya organisasinya. Dari ketujuh karakteristik tersebut yang relevan dengan PT Sayuran Siap Saji yaitu karakteristik yang berorientasi pada hasil dan tim. Budaya organisasi yang berorientasi pada hasil dilakukan perusahaan untuk menyampaikan tujuan akhir secara jelas dari suatu pengerjaan bisnis. Sedangkan budaya organisasi yang berorientasi pada tim cenderung memiliki kepecayaan bahwa bekerja secara bersama-sama akan lebih efektif dalam menyelesaikan pekerjaan. Kadafi (2010) menghasilkan penelitain mengenai pentingnya orientasi hasil dan tim terhadap kinerja dengan implikasi 
yaitu, (1) perhatian untuk mempertahankan budaya kerja, (2) perhatian manajemen terhadap proses seleksi karyawan, dan (3) perhatian terhadap sosialiasi nilai-nilai organisasi.

\begin{tabular}{|c|c|}
\hline $\begin{array}{l}\text { X } \\
\text { Komunikasi Internal } \\
\text { (Markgraf 2003) } \\
\text { X1. Komunikasi dua arah } \\
\text { X2. Kemampuan inter- } \\
\text { personal } \\
\text { X3. Kesadaran dan budaya } \\
\text { risiko } \\
\text { X4. Kejelasan pesan atau } \\
\text { informasi } \\
\text { X5. Frekuensi pesan atau } \\
\text { informasi } \\
\text { X6. Pembelajaran berkala } \\
\text { X7. Tatakelola } \\
\text { pengelolaan risiko } \\
\text { X8. Struktur komunikasi } \\
\text { internal } \\
\text { X9. Pengetahuan } \\
\text { manajemen } \\
\text { X10. Kekuatan leadership }\end{array}$ & $\begin{array}{l}\text { Y } \\
\text { Budaya Organisasi yang } \\
\text { Berorientasi pada Hasil } \\
\text { dan Tim (Kadafi 2010) } \\
\text { Y1. Budaya kerja } \\
\text { a. Kedisiplinan } \\
\text { b. Tanggung } \\
\text { c. jawab } \\
\text { Kerja keras } \\
\text { Y2. Seleksi calon karyawan } \\
\text { a. Kemauan untuk } \\
\text { b. Kelajar } \\
\text { Kemampuan } \\
\text { c. } \quad \text { Kang dimiliki } \\
\text { Y3. Sojialisari } \\
\text { organisasi } \\
\text { a. Nilai-nilai } \\
\text { b. Norma } \\
\text { c. Keyakinan } \\
\text { bersama }\end{array}$ \\
\hline
\end{tabular}

Gambar 1 Kerangka analisis penelitian

\section{Hipotesis}

Berdasarkan kerangka pemikiran yang telah dirancang, hipotesis pada penelitian ini adalah sebagai berikut:

1. Diduga terdapat pengaruh antara komunikasi internal (komunikasi dua arah, kemampuan interpersonal, kesadaran dan budaya risiko, kejelasan pesan atau informasi, frekuensi pesan atau informasi, pembelajaran berkala, tatakelola pengelolaan risiko, struktur komunikasi internal, pengetahuan manajemen, kekuatan leadership) dengan budaya kerja, seleksi calon karyawan, dan sosialisasi pihak organisasi.

2. Diduga terdapat pengaruh antara komunikasi internal (komunikasi dua arah, kemampuan interpersonal, kesadaran dan budaya risiko, kejelasan pesan atau informasi, frekuensi pesan atau informasi, pembelajaran berkala, tatakelola pengelolaan risiko, struktur komunikasi internal, pengetahuan manajemen, kekuatan leadership) dengan budaya organisasi yang berorientasi pada hasil dan tim.

\section{METODE PENELITIAN}

Metode yang digunakan pada penelitian ini adalah metode survey. Pendekatan pada penelitian ini menggunakan pendekatan kuantitatif yang didukung oleh data kualitatif. Data kualitatif untuk mendukung penelitian kuantitatif diperoleh melalui observasi lapang, studi literatur, catatan harian lapang serta wawancara mendalam yang dilakukan kepada informan (Ibu linda HRD PT Sayuran Siap Saji, Mas Firman Kepala Produksi, dan beberapa pekerja di bagian produksi) dengan menggunakan panduan pertanyaan yang dilakukan oleh peneliti di lokasi penelitian. Penelitian ini dilakukan di PT Sayuran Siap Saji, Kampung Pasir Muncang, Desa Sukamanah, Kecamatan Megamendung, 
Kabupaten Bogor. Kegiatan penelitian ini dilaksanakan dalam jangka waktu empat bulan terhitung dari bulan Januari 2018 sampai April 2018.

Unit analisis dalam penelitian ini adalah individu yaitu karyawan PT Sayuran Siap Saji. Jumlah sampel dalam penelitian ini yaitu 30 responden. Teknik pengambilan sampel dalam penelitian ini yaitu stratified random sampling yaitu dengan mengambil (n) dari bagian pihak manajemen dan pihak karyawan. Data yang diperoleh secara kuantitatif melalui kuesioner diolah dengan menggunakan program Microsoft Excel 2013 dan SPSS 21 for Windows. Data dianalisis menggunakan tabel frekuensi dan uji regresi linear berganda. Uji regresi linear berganda digunakan untuk mengetahui pengaruh komunikasi internal (komunikasi dua arah, kemampuan interpersonal, kesadaran dan budaya risiko, kejelasan pesan atau informasi, frekuensi pesan atau informasi, pembelajaran berkala, tatakelola pengelolaan risiko, struktur komunikasi internal, pengetahuan manajemen, kekuatan leadership) dengan budaya organisasi yang berorientasi pada hasil dan tim (budaya kerja, seleksi calon karyawan, sosialisasi pihak organisasi). Pada uji regresi ini, alpha yang ditentukan sebesar 20 persen atau 0.2 dan berarti taraf kepercayaan uji regresi mencapai 80 persen. Persamaan regresi yang digunakan berdasarkan faktor-faktor yang mempengaruhi budaya organisasi yang berorientasi pada hasil dan tim sebagai berikut:

$y=a+b_{1} x_{1}+b_{2} x_{2}+b_{3} x_{3}+b_{4} x_{4}+b_{5} x_{5}+b_{6} x_{6}+b_{7} x_{7}+b_{8} x_{8}+b 9 x_{9}+b_{10} x_{10}$

Keterangan:

$\mathrm{y}=$ budaya organisasi

$\mathrm{a}=$ konstanta

$b_{1,2,3}, \ldots d s t=$ koefisien regresi linier berganda

$\mathrm{x}_{1}=$ komunikasi dua arah

$\mathrm{x}_{2}=$ kemampuan interpersonal

$\mathrm{x}_{3}=$ kesadaran dan budaya risiko

$\mathrm{x}_{4}=$ kejelasan pesan atau informasi

$\mathrm{x}_{5}=$ frekuensi pesan atau informasi

$\mathrm{x}_{6}=$ pembelajaran berkala

$\mathrm{x}_{7}=$ tatakelola pengelolaan risiko

$\mathrm{x}_{8}=$ struktur komunikasi internal

$\mathrm{x}_{9}=$ pengetahuan manajemen

$\mathrm{x}_{10}=$ kekuatan leadership

\section{HASIL DAN PEMBAHASAN}

\section{Karakteristik Responden}

Penelitian ini dilakukan di perusahaan agribisnis yang bernama PT Sayuran Siap Saji, dengan jumlah responden sebanyak 30 responden yang tersebar dalam pihak manajemen dan pihak karyawan. Pihak manajemen dan karyawan memiliki karakteristik individu seperti, usia, jenis kelamin, tingkat pendidikan, lama bekerja, dan tingkat pendapatan. 
Tabel 1 Jumlah dan persentase responden berdasarkan usia, jenis kelamin, tingkat pendidikan, tingkat pendapatan dan lama bekerja, tahun 2018

\begin{tabular}{lcc}
\hline Karakteristik Responden & Jumlah (n) & Persentase (\%) \\
\hline Usia & 2 & 6.7 \\
Remaja (13-20) & 20 & 66.7 \\
Dewasa (20-40) & 8 & 26.7 \\
Setengah baya (40-60) & 30 & 100.0 \\
\hline Total & 26 & 86.7 \\
\hline Jenis kelamin & 4 & 13.3 \\
Perempuan & 30 & 100.0 \\
Laki-laki & & \\
\hline Total & 18 & 60.0 \\
\hline Tingkat Pendidikan & 8 & 26.7 \\
Rendah (SD-SMP) & 4 & 13.3 \\
Sedang (SMA sederajat) & 30 & 100.0 \\
Tinggi (Perguruan Tinggi) & & \\
\hline Total & 20 & 66.7 \\
\hline Tingkat Pendapatan & 0 & 0.0 \\
Rendah (<1.500.000) & & \\
Sedang & 10 & 33.3 \\
(1.500.000 - 2.000.000) & 30 & 100.0 \\
Tinggi (>2.000.000) & & \\
\hline Total & 8 & 26.7 \\
\hline Lama bekerja & 13 & 33.3 \\
$<1$ tahun & 9 & 100.0 \\
$1-5$ tahun & 30 & \\
$>5$ tahun & & \\
\hline Total & & \\
\hline
\end{tabular}

Berdasarkan data pada Tabel 1, mayoritas responden berada pada rentang usia dewasa yaitu umur 20-40 tahun dan mayoritas perempuan. Tingkat pendidikan terakhir yang dimiliki responden kebanyakan adalah SD-SMP sederajat yang termasuk dalam golongan rendah. Responden mayoritas memiliki pendapatan rendah yaitu dibawah Rp1.500.000,00. Mayoritas responden sudah lama bekerja di PT Sayuran Siap Saji yaitu sekitar 1-5 tahun.

\section{PROSES KOMUNIKASI INTERNAL PT SAYURAN SIAP SAJI}

Markgraf (2003) mengungkapkan komunikasi internal yang efektif yang dapat diterapkan di dalam perusahaan, yaitu komunikasi dua arah, kemampuan inter-personal, kesadaran dan budaya risiko, kejelasan pesan/informasi, frekuensi pesan/informasi, pembelajaran berkala, tatakelola pengelolaan risiko, struktur komunikasi internal, pengetahuan manajemen dan kekuatan leadership.

\section{Komunikasi Dua Arah}

Komunikasi dua arah merupakan proses komunikasi yang didalam prosesnya terdapat feedback atau umpan balik yang dijalankan dari pihak manajemen ke karyawan maupun dari arah sebaliknya. Komunikasi dua arah meliputi komunikasi vertikal ke bawah, vertikal ke atas dan komunikasi horizontal. 
Tabel 2 Jumlah dan persentase komunikasi dua arah di PT Sayuran Siap Saji 2018

\begin{tabular}{lcc}
\hline \multicolumn{1}{c}{ Komunikasi dua arah } & Jumlah $(\mathrm{n})$ & Persentase $(\%)$ \\
\hline Rendah & 5 & 16.7 \\
Sedang & 20 & 66.7 \\
Tinggi & 5 & 16.7 \\
\hline Total & 30 & 100.0 \\
\hline
\end{tabular}

Sebagian besar responden beranggapan bahwa sebanyak 66.7 persen komunikasi dua arah yang terjalin di PT Sayuran Siap Saji dapat dikategorikan sedang. Responden menyatakan bahwa komunikasi dua arah yang terjalin sudah cukup baik dari tahun sebelumnya tapi tidak bisa dikatakan baik sekali juga, setidaknya beberapa kesalahpahaman seperti menampung keluhan karyawan, memberikan pendapat mengenai produk, kesalahan memotong ukuran sayuran, perizinan sakit yang melebihi batas izin dan kesalahpahaman lainnya dapat diselesaikan dengan komunikasi dua arah yang cukup baik antara karyawan dengan atasannya.

\section{Kemampuan inter-personal}

Kemampuan inter-personal merupakan kemampuan yang dimiliki secara pribadi pada diri masing-masing seseorang, kemampuan ini sendiri satu orang dengan yang lainnya memiliki kemampuan yang berbeda-beda.

Tabel 3 Jumlah dan persentase kemampuan inter-personal di PT Sayuran Siap Saji 2018

\begin{tabular}{lcc}
\hline Kemampuan inter-personal & Jumlah $(\mathrm{n})$ & Persentase $(\%)$ \\
\hline Rendah & 7 & 23.3 \\
Sedang & 17 & 56.7 \\
Tinggi & 6 & 20.0 \\
\hline Total & 30 & 100.0 \\
\hline
\end{tabular}

Kemampuan inter-personal yang dimiliki oleh karyawan PT Sayuran Siap Saji termasuk dalam kategori sedang atau dapat dikatakan baik dengan persentase 56.7 persen. Sesuai dengan keadaan di lapang, yaitu banyaknya karyawan senior dalam perusahaan menjadikan karyawan memiliki kemampuan inter-personal yang baik. Seiring berjalannya waktu dan seiring lamanya mereka bekerja menjadikan mereka dapat memahami hal-hal yang ada dalam perusahaan dengan cara mereka sendiri maupun pengalaman-pengalaman yang mereka dapatkan selama bekerja di PT Sayuran Siap Saji.

\section{Kesadaran dan Budaya Risiko}

Kesadaran dan budaya risiko merupakan perilaku dan sikap yang mana jika terdapat potensi risiko baik sebelum ada risiko atau sesudah terjadi risiko, karyawan secara langsung harus mampu mengidentifikasi dan menyadari risiko.

Tabel 4 Jumlah dan persentase kesadaran dan budaya risiko di PT Sayuran Siap Saji 2018

\begin{tabular}{lcc}
\hline Kesadaran dan budaya risiko & Jumlah (n) & Persentase (\%) \\
\hline Rendah & 6 & 20.0 \\
Sedang & 19 & 63.3 \\
Tinggi & 5 & 16.7 \\
\hline Total & 30 & 100.0 \\
\hline
\end{tabular}


Jawaban responden mengenai kesadaran dan budaya risiko didominasi pada golongan sedang, yaitu sebesar 63.3 persen. Hal ini sesuai di lapang yaitu dikarenakan pihak manajemen atau pimpinan yang kurang sering menjelaskan mengenai apa itu kesadaran dan budaya risiko pada perusahaan. Seharusnya kesadaran dan budaya risiko yang dimiliki responden tinggi, agar para karyawan sudah mampu menganalisis risiko-risiko yang kemungkinan terjadi dengan sigap.

\section{Kejelasan Pesan/Informasi}

Kejelasan pesan atau informasi di dalam PT Sayuran Siap Saji merupakan proses pengiriman dan penerimaan pesan atau informasi yang memerlukan persepsi yang sama untuk menghindari kesalahpahaman dalam mengirim dan menerima pesan atau informasi yang disampaikan.

Tabel 5 Jumlah dan persentase kejelasan pesan atau informasi di PT Sayuran Siap Saji 2018

\begin{tabular}{lcc}
\hline Kejelasan pesan atau informasi & Jumlah $(\mathrm{n})$ & Persentase $(\%)$ \\
\hline Rendah & 5 & 16.7 \\
Sedang & 19 & 63.3 \\
Tinggi & 6 & 20.0 \\
\hline Total & 30 & 100.0 \\
\hline
\end{tabular}

Mayoritas responden yang melakukan pengiriman dan penerimaan pesan dengan karyawan lainnya atau dengan pihak pimpinan sudah dalam konteks cukup baik sebesar 63.3 persen. Hal tersebut dikarenakan kejelasan pesan atau informasi sangat penting dalam lingkungan pekerjaan, jika pesan atau informasi yang disampaikan oleh pengirim sudah salah maka seseorang yang menerima pesan atau informasi tersebut akan meanggapnya benar saja karena penerima pesan tidak mengetahui pesan dan informasi yang benar atau salah itu seperti apa dan bagaimana.

\section{Frekuensi Pesan/Informasi}

Frekuensi pesan atau informasi adalah suatu aspek yang melihat intensitas responden dalam memperoleh pesan atau informasi di dalam perusahaan.

Tabel 6 Jumlah dan persentase frekuensi pesan atau informasi di PT Sayuran Siap Saji 2018

\begin{tabular}{lcc}
\hline Frekuensi pesan atau informasi & Jumlah (n) & Persentase (\%) \\
\hline Rendah & 8 & 26.7 \\
Sedang & 15 & 50.0 \\
Tinggi & 7 & 23.3 \\
\hline Total & 30 & 100.0 \\
\hline
\end{tabular}

Jawaban responden mengenai frekuensi pesan atau informasi didominasi golongan sedang, yaitu sebesar 50.0 persen. Berdasarkan fakta di lapang mereka mengatakan penyampaian pesan atau informasi lebih baik dilakukan secara tatap muka atau langsung dari sumbernya, bukan dari orang lain atau pun dari media lain yang hasilnya bisa saja terdapat kekurangan atau dilebih-lebihkan. 


\section{Pembelajaran Berkala}

Pembelajaran berkala adalah salah satu bentuk usaha yang dilakukan oleh perusahaan untuk melakukan refreshment atau sosialisasi terhadap karyawannya secara berkala agar meningkatkan soft skill dan hard skill yang dimiliki.

Tabel 7 Jumlah dan persentase pembelajaran berkala di PT Sayuran Siap Saji 2018

\begin{tabular}{lcc}
\hline \multicolumn{1}{c}{ Pembelajaran berkala } & Jumlah $(\mathrm{n})$ & Persentase $(\%)$ \\
\hline Rendah & 6 & 20.0 \\
Sedang & 19 & 63.3 \\
Tinggi & 5 & 16.7 \\
\hline Total & 30 & 100.0 \\
\hline
\end{tabular}

Pembelajaran berkala yang diterima oleh responden tergolong sedang yaitu sebesar 63.3 persen. Hal ini sesuai dengan fakta di lapang, dimana responden menjawab bahwa pembelajaran berkala seperti pelatihan, diskusi dengan pimpinan atau manajer jarang dilakukan, terkecuali terjadi komplain dari pelanggan maka akan dilakukan evaluasi terus-menerus yang salah satunya itu meningkatkan pelatihan bagi karyawan dan intensitas diskusi bersama antara atasan dan bawahan agar saling mengetahui fakta yang ada.

\section{Tatakelola Pengelolaan Risiko}

Tatakelola pengelolaan risiko adalah pemantauan yang dilakukan oleh jenjang komite atau bagian para petinggi perusahaan yang dilakukan secara berkala untuk mengelola risiko dengan cara meminimalisir setiap risiko yang terjadi, baik itu risiko perusahaan maupun risiko terhadap konsumen.

Tabel 8 Jumlah dan persentase tatakelola pengelolaan risiko di PT Sayuran Siap Saji 2018

\begin{tabular}{lcc}
\hline \multicolumn{1}{c}{ Tatakelola pengelolaan risiko } & Jumlah $(\mathrm{n})$ & Persentase $(\%)$ \\
\hline Rendah & 2 & 6.7 \\
Sedang & 23 & 76.7 \\
Tinggi & 5 & 16.7 \\
\hline Total & 30 & 100.0 \\
\hline
\end{tabular}

Mayoritas responden sebesar 76.7 persen merasakan adanya pemantauan yang dilakukan oleh para ketua divisi dan juga pihak manajemen khususnya di bagian produksi. Berdasarkan pengamatan di lapang, bagian manajemen memiliki tanggung jawab tersendiri dalam pengelolaan risiko yang terjadi baik dari bagian keuangan, pemasaran atau pun bagian lainnya yang berada di bagian manajamen. Sedangkan bagian karyawan produksi mereka merasa hampir setiap harinya manajer produksi serta kepala produksi melakukan pemantauan secara teratur, mulai dari pemantauan mengenai barang yang baru datang, pemantauan terhadap alat-alat yang sering digunakan, sampai kepada pemantauan terhadap karyawan yang sedang melakukan pen-sortiran produk maupun pengepakan barang yang akan siap kirim.

\section{Struktur Komunikasi Internal}

Struktur komunikasi internal adalah lapis pertahanan pengelolaan risiko operasional atau kelangsungan usaha yang telah berjalan efektif. Struktur komunikasi internal diukur berdasarkan tujuan dari komunikasi internal yang ingin disampaikan. 
Tabel 9 Jumlah dan persentase struktur komunikasi internal di PT Sayuran Siap Saji 2018

\begin{tabular}{lcc}
\hline \multicolumn{1}{c}{ Struktur komunikasi internal } & Jumlah (n) & Persentase (\%) \\
\hline Rendah & 8 & 26.7 \\
Sedang & 18 & 60.0 \\
Tinggi & 4 & 13.3 \\
\hline Total & 30 & 100.0 \\
\hline
\end{tabular}

Sebanyak 60.0 persen menunjukkan bahwa struktur komunikasi internal tergolong kedalam kategori sedang. Hasil pengamatan di lapang, responden mengatakan proses komunikasi internal yang terjalin antara karyawan biasa dengan pihak manajemen atau dengan manajernya terbilang cukup jarang. Komunikasi internal yang dianggap sebagai salah satu solusi dalam mengurangi risiko yang ada, dianggap tidak begitu megambil peran banyak karena komunikasi internal di dalam PT Sayuran Siap Saji digunakan ketika adanya komplain dari konsumen mengenai produk yang tidak sesuai dengan keinginan konsumen.

\section{Pengetahuan Manajemen}

Pengetahuan manajemen merupakan pemahaman mengenai manajemen atas alur komunikasi untuk pengelolaan risiko operasional dan kelangsungan usaha.

Tabel 10 Jumlah dan persentase pengetahuan manajemen di PT Sayuran Siap Saji 2018

\begin{tabular}{lcc}
\hline \multicolumn{1}{c}{ Pengetahuan manajemen } & Jumlah (n) & Persentase $(\%)$ \\
\hline Rendah & 4 & 13.3 \\
Sedang & 18 & 60.0 \\
Tinggi & 8 & 26.7 \\
\hline Total & 30 & 100.0 \\
\hline
\end{tabular}

Pengetahuan manajemen yang dimiliki responden mengenai pengelolaan risiko di PT Sayuran Siap Saji tergolong sedang yaitu sebesar 60.0 persen. Hal ini menunjukkan bahwa pengetahuan manajemen yang dimiliki oleh karyawan PT Sayuran Siap Saji mengenai pengelolaan risiko dapat dikatakan cukup baik, yaitu ketika karyawan menghadapi beberapa risiko seperti berhati-hati terhadap alat-alat yang mudah terbakar, contoh hal yang berbahaya seperti gas di dalam ruangan.

\section{Kekuatan Leadership}

Kekuatan leadership merupakan peranan yang dimiliki secara pribadi oleh pimpinan dalam pengelolaan risiko operasional dan kelangsungan usaha.

Tabel 11 Jumlah dan persentase kekuatan leadership di PT Sayuran Siap Saji 2018

\begin{tabular}{lcc}
\hline \multicolumn{1}{c}{ Kekuatan leadership } & Jumlah (n) & Persentase (\%) \\
\hline Rendah & 6 & 20.0 \\
Sedang & 7 & 23.3 \\
Tinggi & 17 & 56.7 \\
\hline Total & 30 & 100.0 \\
\hline
\end{tabular}

Kekuatan leadership yang berada di PT Sayuran Siap Saji tergolong dalam kategori tinggi dengan persentase sebesar 56.7 persen. Hal ini menunjukkan bahwa peran pimpinan sangat berpengaruh dalam pengelolaan risiko yang terjadi dalam perusahaan. Pihak PT Sayuran Siap Saji menganggap selain karyawan yang menjadi hal utama dalam pembentukan citra perusahaan, kekuatan leadership juga 
dianggap sebagai salah satu yang membantu pembentukkan citra tersebut. Kekuatan leadership dapat terlihat dari pimpinan yang mampu bersikap koperatif dengan para karyawannya, yaitu pimpinan mau mendengarkan keluhan, memberikan tanggapan terhadap hasil pekerjaan karyawannya.

\section{KARAKTERISTIK BUDAYA ORGANISASI BERORIENTASI PADA HASIL DAN TIM PT SAYURAN SIAP SAJI}

Budaya organisasi adalah suatu sistem nilai-nilai yang dirasakan maknanya oleh seluruh orang dalam organisasi. Hasil penelitian Kadafi (2010) menyimpulkan bahwa kerjasama tim dan orientasi hasil mempunyai peranan yang sangat penting terhadap kinerja pada suatu organisasi, implikasi penting bagi organisasi diantaranya perhatian untuk mempertahankan budaya kerja, perhatian manajemen terhadap proses seleksi karyawan, dan perhatian terhadap sosialiasi nilai-nilai organisasi. Budaya organisasi yang melekat pada PT Sayuran Siap Saji adalah budaya organisasi yang berorientasi pada hasil dan tim.

\section{Budaya Kerja}

Budaya kerja meliputi sikap, mental, keinginan maju, percaya pada diri sendiri, dan keseluruhan hal tersebut akan tercermin dan mempengaruhi pekerjaan para karyawan setiap harinya di PT Sayuran Siap Saji. Budaya kerja pada PT Sayuran Siap Saji, secara umum dilihat dari segi kedisiplinan, tanggung jawab dan kerja keras dari seluruh karyawannya.

Tabel 12 Jumlah dan persentase budaya kerja di PT Sayuran Siap Saji 2018

\begin{tabular}{|c|c|c|}
\hline Budaya kerja & Jumlah (n) & Persentase (\%) \\
\hline Rendah & 2 & 6.7 \\
\hline Sedang & 24 & 80.0 \\
\hline Tinggi & 4 & 13.3 \\
\hline Total & 30 & 100.0 \\
\hline
\end{tabular}

Sebanyak 80.0 persen responden tergolong dalam kategori sedang yang dianggap sudah cukup baik dalam pelaksanaanya. Hal ini sesuai dengan fakta di PT Sayuran Siap Saji yang sudah mampu menjadikan karyawannya disiplin dalam bekerja yaitu berkurangnya keterlambatan karyawan, dan bertanggung jawab terhadap kerjaan lembur yang didapatkan. Kerja lembur yang dilakukan oleh karyawan juga dianggap sebagai cerminan kerja keras yang didedikasikan oleh para karyawan untuk perusahaan.

\section{Seleksi Calon Karyawan}

Seleksi calon karyawan merupakan langkah pertama yang dilakukan oleh perusahaan untuk mendapatkan calon pegawai atau karyawan yang sesuai dengan yang dibutuhkan oleh perusahaan.

Tabel 13 Jumlah dan persentase seleksi calon karyawan di PT Sayuran Siap Saji 2018

\begin{tabular}{lcc}
\hline \multicolumn{1}{c}{ Seleksi calon karyawan } & Jumlah (n) & Persentase $(\%)$ \\
\hline Rendah & 18 & 60.0 \\
Sedang & 5 & 16.7 \\
Tinggi & 7 & 23.3 \\
\hline Total & 30 & 100.0 \\
\hline
\end{tabular}


Mayoritas responden sebesar 60.0 persen beranggapan bahwa seleksi calon karyawan yang ada di PT Sayuran Siap Saji berada pada kategori rendah. Hal ini sejalan dengan data di lapang, yaitu sebagian besar responden tidak menjalani proses seleksi calon karyawan secara rumit melainkan persyaratan dari perusahaan untuk karyawan produksi yaitu mau bekerja keras, jujur, tanggung jawab dan mampu bekerja dibawah tekanan. Sedangkan untuk melamar pada bagian manajemen perusahaan memberikan persyaratan seleksi yang berbeda kepada calon pelamar.

\section{Sosialisasi Pihak Organisasi}

Sosialisasi merupakan usaha yang dilakukan oleh suatu perusahaan untuk menerangkan, menjelaskan, memberikan contoh dan hal lainnya berupa informasi-informasi mengenai perusahaan.

Tabel 14 Jumlah dan persentase sosialisasi pihak organisasi di PT Sayuran Siap Saji 2018

\begin{tabular}{lcc}
\hline \multicolumn{1}{c}{ Sosialisasi pihak organisasi } & Jumlah $(\mathrm{n})$ & Persentase $(\%)$ \\
\hline Rendah & 3 & 10.0 \\
Sedang & 19 & 63.3 \\
Tinggi & 8 & 26.7 \\
\hline Total & 30 & 100.0 \\
\hline
\end{tabular}

Sebanyak 63.3 persen menunjukkan bahwa sosialisasi yang diberikan oleh perusahaan masuk dalam kategori sedang. Hasil pengamatan di lapang, sosialisasi diberikan kepada karyawan baru atau pengenalan produk baru yang perlu dijelaskan proses pengerjaannya, seperti cara-caranya (pencucian, pemotongan, pengepakan), standar barangnya harus seperti apa, dan perlakuan terhadap barangnya juga harus seperti apa, semua hal tersebut wajib dijelaskan kepada karyawan untuk mengurangi kesalahan yang terjadi. Maka dari itu kategori sosialisasi ini tergolong sudah cukup baik, karena perusahaan memberikan sosialisasi mengenai hal-hal yang ada di perusahaan baik hal baru mengenai cara pengerjaan produk baru, maupun sosialisasi mengenai hal-hal yang boleh dan tidak boleh dilakukan di perusahaan.

\section{FAKTOR-FAKTOR YANG MEMPENGARUHI KOMUNIKASI INTERNAL DALAM MEMBANGUN BUDAYA ORGANISASI PT SAYURAN SIAP SAJI}

Komunikasi internal dapat dipahami sebagai pondasi dan bangunan dari sebuah budaya organisasi. Budaya organisasi menentukan atmosfer kerja dalam sebuah perusahaan berdasarkan nilai-nilai, misi perusahaan, dan proses kerja. Ketika seluruh anggota perusahaan telah memegang nilai-nilai yang sama, memahami pedoman kerja dan misi perusahaan secara mendetail, maka budaya organisasi akan lebih secara nyata memberikan kontribusi bagi perkembangan suatu perusahaan. Komunikasi internal dalam membangun budaya organisasi terdiri dari komunikasi dua arah, kemampuan interpersonal, kesadaran dan budaya risiko, kejelasan pesan atau informasi, frekuensi pesan atau informasi, pembelajaran berkala, tatakelola pengelolaan risiko, struktur komunikasi internal, pengetahuan manajemen, kekuatan leadership. Pengujian faktor-faktor tersebut dilakukan secara bersamaan dengan memasukkan seluruh variabel pengaruh sebagai variabel independen dan melihat pengaruhnya pada masing-masing variabel dependen yaitu budaya organisasi yang berorientasi pada hasil dan tim 
yang terdiri dari budaya kerja, seleksi calon karyawan dan sosialisasi pihak organisasi. Pada uji regresi ini, alpha yang ditentukan sebesar 20 persen atau 0.2 dan berarti taraf kepercayaan uji regresi mencapai 80 persen.

Tabel 15 Nilai signifikansi pengaruh faktor-faktor komunikasi internal dalam membangun budaya organisasi berorientasi hasil dan tim (budaya kerja, seleksi calon karyawan, sosialisasi pihak organisasi)

\begin{tabular}{|c|c|c|c|}
\hline \multirow[b]{2}{*}{ Variabel } & \multicolumn{3}{|c|}{ Signifikansi } \\
\hline & Budaya kerja & $\begin{array}{l}\text { Seleksi calon } \\
\text { karyawan }\end{array}$ & $\begin{array}{l}\text { Sosialisasi pihak } \\
\text { organisasi }\end{array}$ \\
\hline Komunikasi dua arah & 0.351 & 0.956 & 0.650 \\
\hline Kemampuan inter-personal & 0.623 & $0.069^{*}$ & 0.328 \\
\hline Kesadaran dan budaya risiko & 0.897 & 0.418 & 0.865 \\
\hline Kejelasan pesan/informasi & 0.311 & 0.327 & 0.898 \\
\hline Frekuensi pesan/informasi & $0.098^{*}$ & $0.003^{*}$ & 0.815 \\
\hline Pembelajaran berkala & 0.749 & 0.272 & 0.994 \\
\hline Tatakelola pengelolaan risiko & $0.033^{*}$ & $0.178^{*}$ & 0.586 \\
\hline Struktur komunikasi internal & 0.547 & 0.698 & 0.595 \\
\hline Pengetahuan manajemen & 0.557 & 0.619 & 0.390 \\
\hline Kekuatan leadership & 0.873 & 0.926 & 0.621 \\
\hline
\end{tabular}

Faktor-faktor yang mempengaruhi komunikasi internal terhadap budaya kerja adalah variabel frekuensi pesan atau informasi dan tatakelola pengelolaan risiko. Frekuensi pesan atau informasi dan tatakelola pengelolaan risiko memiliki nilai signifkasi $<0.20$ sehingga memiliki pengaruh terhadap komponen budaya kerja. Hal ini menunjukkan bahwa frekuensi pesan atau informasi di dalam perusahaan menjadi faktor penting bagi para responden ketika mereka berkomunikasi dan juga menerima pesan atau informasi yang lebih sering dan secara langsung. Selain itu tatakelola pengelolaan risiko di dalam perusahaan memiliki pengaruh untuk meningkatkan sikap dan perilaku mereka dalam bekerja, dimana tatakelola pengelolaan risiko ini merupakan salah satu kegiatan yang dilakukan perusahaan untuk memantau keadaan lapang dari para karyawannya.

Faktor-faktor yang mempengaruhi komunikasi internal terhadap seleksi calon karyawan adalah variabel kemampuan inter-personal, frekuensi pesan atau informasi dan tatakelola pengelolaan risiko. Kemampuan inter-personal dapat menjadi pertimbangan dalam perekrutan calon karyawan baru. Fakta di lapang responden telah memiliki kemampuan inter-personal yang cukup baik, hal ini akan berpengaruh terhadap perekrutan calon karyawan baru yaitu dengan merubah standar perekrutan calon karyawan baru minimal sama dengan kemampuan para karyawan yang sudah bekerja di perusahaan. Frekuensi dalam penerimaan pesan atau informasi oleh responden berpengaruh terhadap peningkatan standarisasi perekrutan karyawan baru, dimana responden telah mampu bekomunikasi dengan baik yaitu dengan seringnya mendapatkan pesan atau informasi yang diperoleh dari lingkungan perusahaan. Seleksi calon karyawan juga dapat dipengaruhi oleh tatakelola pengelolaan risiko, dimana dalam proses pengelolaan risiko dibutuhkan sumber daya yang kompeten dalam menangani risiko-risiko yang kemungkinan terjadi dalam perusahaan. 
Faktor-faktor yang mempengaruhi komunikasi internal terhadap sosialisasi pihak organisasi yaitu tidak berpengaruh. Tidak ada variabel yang signifikan berpengaruh karena semua variabel tidak memiliki nilai alpha $<0.20$.

Tabel 16 Nilai signifikansi pengaruh faktor-faktor komunikasi internal dalam membangun budaya organisasi

\begin{tabular}{lc}
\hline \multicolumn{1}{c}{ Variabel } & Signifikansi \\
\cline { 2 - 3 } & Budaya organisasi berorientasi pada hasil dan tim \\
\hline Komunikasi dua arah & 0.828 \\
Kemampuan inter-personal & $0.156^{*}$ \\
Kesadaran dan budaya risiko & 0.664 \\
Kejelasan pesan/informasi & 0.325 \\
Frekuensi pesan/informasi & $0.008^{*}$ \\
Pembelajaran berkala & 0.424 \\
Tatakelola pengelolaan risiko & 0.528 \\
Struktur komunikasi internal & 0.697 \\
Pengetahuan manajemen & 0.957 \\
Kekuatan leadership & 0.868 \\
\hline
\end{tabular}

Faktor-faktor yang mempengaruhi komunikasi internal dalam membangun budaya organisasi yang berorientasi pada hasil dan tim yang signifikan mempengaruhi adalah variabel kemampuan inter-personal dan frekuensi pesan atau informasi, yaitu memiliki nilai signifikansi $<0.20$ sehingga memiliki pengaruh yang nyata antara komunikasi internal terhadap budaya organisasi yang berorientasi pada hasil dan tim. kemampuan inter-personal berperan penting dalam membangun budaya organisasi yang berorientasi pada hasil dan tim, dimana responden dengan kemampuan inter-personal yang cukup baik akan mendorong kerjasama tim di PT Sayuran Siap Saji dan juga akan sejalan dengan hasil yang maksimal. Selain itu frekuensi pesan atau informasi juga berpengaruh dalam membangun budaya organisasi yang berorientasi pada hasil dan tim, dimana dengan seringnya responden mendapatkan atau diberikan suatu informasi mengenai pekerjaan akan berpeluang lebih tinggi dalam memaksimalkan pekerjaannya.

\section{KESIMPULAN DAN SARAN}

\section{Kesimpulan}

Sesuai dengan hasil penelitian yang telah dijabarkan sebelumnya dapat dibuat kesimpulan seperti berikut:

1. Proses komunikasi internal yang terjalin di PT Sayuran Siap Saji tergolong cukup efektif, salah satu variabel komunikasi internal yang terkategori tinggi yaitu kekuatan leadership. Variabel kekuatan leadership yang dimiliki responden cenderung homogen yang mayoritas terkategori tinggi, sedangkan variabel budaya organisasi menurut responden memiliki hasil yang bervariasi. Hal ini menyebabkan kekuatan leadership tidak siginifikan berpengaruh terhadap budaya organisasi. Selain itu, nilai p-value dari kekuatan leadership lebih besar dari nilai alpha (>0.20) yang mengakibatkan tidak signifikan berpengaruh. Meskipun tidak berpengaruh, kekuatan leadership dianggap penting oleh karyawan PT Sayuran Siap Saji karena kekuatan leadership merupakan contoh atau acuan dalam melakukan pekerjaan di perusahaan. 
2. Bentuk komunikasi internal yang ada di PT Sayuran Siap Saji yaitu adanya rapat manajemen sebulan sekali, rapat koordinasi setiap minggu, dan evaluasi karyawan dapat dikatakan tentatif atau tergantung kebutuhan dari masingmasing manajer.

3. Budaya organisasi yang berada di PT Sayuran Siap Saji tergolong cukup baik, yaitu budaya organisasi yang ada di perusahaan secara umum berorientasi terhadap hasil dan tim yang terdiri dari budaya kerja, seleksi calon karyawan dan sosialisasi pihak organisasi. Budaya kerja dan sosialisasi pihak organisasi menurut responden terkategori sedang, sedangkan hanya seleksi calon karyawan yang terkategori rendah. Seleksi calon karyawan terkategori rendah dengan persentase $60 \%$ menurut 18 responden, dan sesuai dengan fakta di lapang bahwa seleksi calon karyawan yang ada di PT Sayuran Siap Saji belum diterapkan untuk seluruh karyawan, melainkan hanya karyawan bagian manajemen yang menjalani proses seleksi calon karyawan, sisanya hanya di wawancarai dengan sederhana dengan persyaratan mau bekerja keras dan disiplin waktu.

4. Faktor-faktor yang mempengaruhi komunikasi internal dalam membangun budaya organisasi yang berorientasi pada hasil dan tim pada komponen budaya kerja adalah frekuensi pesan atau informasi dan tatakelola pengelolaan risiko, pada komponen seleksi calon karyawan yang berpengaruh adalah kemampuan inter-personal, frekuensi pesan atau informasi dan tatakelola pengelolaan risiko, sedangkan pada komponen sosialisasi pihak organisasi tidak ada faktor yang berpengaruh.

\section{Saran}

Saran yang dapat diberikan sesuai dengan hasil yang didapatkan pada penelitian ini adalah:

1. PT Sayuran Siap Saji perlu meningkatkan dan mengkaji ulang proses komunikasi internal yang terjalin di dalam perusahaan agar karyawan dapat terlibat lebih intens dalam proses pengambilan keputusan, diskusi dan pertukaran pendapat. Seperti mempertahankan aspek kekuatan leadership untuk mempengaruhi karyawan bersikap positif, dan meningkatkan aspek kesadaran dan budaya risiko kepada seluruh karyawan. Aspek kejelasan pesan/informasi dan aspek frekuensi pesan/informasi dapat dijadikan satu kesatuan agar lebih dimengerti.

2. Pada kasus ini diperlukan penambahan sampel serta faktor lain yang berpotensi mempengaruhi budaya organisasi, agar terlihat sejauh mana budaya organisasi menjadi penentu atmosfer dalam bekerja.

3. Pada penelitian selanjutnya perlu dikaji ulang mengenai variabel seleksi calon karyawan agar lebih disesuaikan dalam pemilihan indikatornya.

4. Perusahaan perlu mengadakan pelatihan kembali dan memberikannya minimal 3 bulan sekali bagi seluruh karyawan sesuai dengan bidang pekerjaan yang mereka kerjakan, agar ilmu dan keterampilan yang didapatkan karyawan menjadi meningkat.

\section{DAFTAR PUSTAKA}

[UU] Undang-undang Nomor 13 tahun 2013 tentang Ketenagakerjaan.

Andjani MD, Prianti DD. 2010. Internal Communication Towards Employee Engagement Inside Sultan Agung Islamic University (UNISSULA). [Internet]. [Diunduh tanggal 
21 Oktober 2017]. Dapat diunduh di: http://jurnal.unissula.ac.id/index.php/ makna/article/view/92/69

Argenti PA. 2013. Corporate Communication. Singapore: McGraw-Hill International Edition.

Doloksaribu ETN. 2010. Pengaruh Gaya Kepemimpinan terhadap Budaya Organisasi PT Pro Car International Finance. [Skripsi]. [Diunduh tanggal 21 Oktober 2017]. Dapat diunduh di: http://repository.ipb.ac.id/handle/123456789/62555

Effendy OU. 2008. Dinamika Komunikasi. Bandung: PT. Remaja Rosdakarya.

Harsono AY, Supratomo, Farid M. 2015. Analisis Gaya Kepemimpinan dan Komunikasi Organisasi antara Atasan-Bawahan dalam Membangun Budaya Organisasi di Lingkungan Sekretariat DPRD Kota Bengkulu. [Internet]. [Diunduh tanggal 21 Oktober 2017]. Dapat diunduh di: http://journal.unhas.ac.id/index.php/kareba/ article/view/630/450

Kadafi M. 2010. Pentingnya Kerjasama Tim Dan Orientasi Hasil Terhadap Kinerja Karyawan. [Internet]. [Diunduh tanggal 7 Februari 2018]. Dapat diunduh di: http://karyailmiah.polnes.ac.id/Download-PDF/EKSIS-VOL.06-NO.2AGUSTUS-2010/NO\%20-\%2014\%20-\%20khadapi\%20\%20PENTINGNYA\%20KERJASAMA\%20TIM\%20DAN\%20ORIENTASI\%20 HASIL\%20TERHADAP\%20KINERJA\%20KARYAWAN.pdf

Markgraf, P.R. 2003. A study of internal communication in the Royal Canadian Mounted Police of Britisth Columbia. Royal Roads University. [Internet]. [Diunduh tanggal 20 Januari 2018]. Dapat diunduh di: http://www.collectionscanada.gc.ca/obj/s4/f2/dsk4/etd/MQ82418.PDF

Melina C, Ratnawati I. 2012. Analisis Pengaruh Budaya Organisasi dan Kepuasan Kerja terhadap Komitmen Organisasional dalam Meningkatkan Kinerja Karyawan (Studi pada PT. Sido Muncul Kaligawe Semarang). [Internet]. [Diunduh tanggal 11 Oktober 2017]. Dapat diunduh di: https://www.unisbank.ac.id/ojs/index.php/fe3/article/view/1740

Morissan. 2009. Teori Komunikasi Organisasi. Bogor (ID): Ghalia Indonesia.

Orsini, B. (2000), Improving Internal Communications, Internal AuditorDec. 2000, Vol. 57, Issue 6,p. 28, 6 pp

Putranto DI. 2012. Pengaruh Komunikasi Internal, Kompensasi Kerja, dan Lingkungan Kerja terhadap Kepuasan Kerja Karyawan pada PT. Kimia Farma Plant Semarang. [Internet]. [Diunduh tanggal 4 Oktober 2017]. Dapat diunduh di: http://ejournal3.undip.ac.id/index.php/jiab/article/view/1623/1617

Ridwan A. 2016. Komunikasi Antarbudaya. Bandung (ID): CV Pustaka Setia.

Robbins SP. 2002. Prinsip-prinsip Perilaku Organisasi. Ed ke-5. Jakarta (ID): Erlangga.

Smith, A. 1991.Innovative Employee Communication: New Approaches to ImprovingTrust, Teamwork \& Performance. New Jersey: Prentice Hall, Publishers.

Suprapto T. 2011. Pengantar Ilmu Komunisasi dan Peran Manajemen dalam Komunikasi. Yogyakarta: Center for Academic Publishing Service (CAPS).

Sutrisno E. 2010. Budaya Organisasi. Jakarta: Kencana Prenada Media Group.

Tsai, W. 2001. Knowledge Transfer in Intraorganizational Networks: Effects of Network Position and Absorptive Capacity on Business Unit Innovation and Performance, Academy of Management Journal, Biarcliff Manor, Vol. 44, Issue 5, p. 996-1004. 